\title{
Beyond the Life Sentence - A Children's Rights Lens on Sentencing for Murder
}

\author{
Yannick van den Brink | ORCID: o0 00-0002-3892-0166 \\ Associate Professor, Department of Criminal Law and Criminology, Vrije \\ Universiteit Amsterdam, Amsterdam, The Netherlands \\ Rubicon Research Fellow, Institute of Criminology, University of Cambridge, \\ Cambridge, United Kingdom \\ y.n.vanden.brink@vu.nl
}

Nessa Lynch | ORCID: 0000-0003-4707-2514

Associate Professor, Faculty of Law, Te Herenga Waka - Victoria

University of Wellington, Wellington, New Zealand nessa.lynch@vuw.ac.nz

\begin{abstract}
Children around the world who have been found responsible for murder continue to be sentenced to indeterminate or long periods of detention. This is in contravention of children's rights standards which urge a ban on the life sentence and require that detention is used only for the shortest appropriate period of time. Nonetheless, the public and victims of crime have a legitimate interest in the protection of public safety and appropriate accountability for serious offending. Further, there is little guidance on what a rights compliant approach in such cases might involve. This work builds on previous studies of how children are sentenced for murder across the common law world and extends the analysis to a selection of European civil law jurisdictions. It explores and applies recent updated guidance from the Committee on the Rights of the Child and seeks to develop a framework for a children's rights and human rights compliant approach to such cases.
\end{abstract}

\section{Keywords}

youth justice - child justice - murder - sentencing - children's rights 


\section{Introduction}

Cases of child-perpetrated murder are particularly emotive and attract a high degree of public and media interest. For instance, the recent murder in Ireland of a 14-year old female victim by two 13-year old male children, with one of the children also convicted of aggravated sexual assault against the victim, made headlines around the world (Carroll, 2019; Press Association, 2019). While instances of murder perpetrated by children are relatively rare (approx. 5 per cent of homicide suspects according to a recent global study (UNODC, 2019)), such cases may catalyse significant law and policy changes (Hay, 1995; Green, 2008), and present conceptual and practical challenges.

Scholars have analysed penal responses to child-perpetrated murder from various disciplinary perspectives, including that of developmental science (Scott Steinberg, 2009; Kloepfer, 2012; Steinberg, 2017), penological theory (Keller, 2012; Dobscha 2019) and socio-political theory (Green, 2008). This article centres children's rights and human rights as its theoretical framework. This article scaffolds on previous work (Lynch, 2018a). It extends the comparative analysis of penal responses to children who commit murder, and further elucidates what a children's rights-compliant response to serious offending by children should involve (Lynch 2018b, 2018c; 2019; Lynch and Liefaard, 2020).

This article first outlines global responses to children who commit murder, before analysing relevant human rights standards and establishing the "four pillars" of a rights-compliant child justice system. This article then presents the findings of a comparative study of (national) legal frameworks that regulate sentencing of children for murder, discussing whether civil law European jurisdictions in fact employ a more tolerant and child-friendly approach to the sentencing of murder than anglophile common law countries. Utilising comparative examples, particularly a case study from the Netherlands, this article ultimately aims to advance understanding of the conceptual challenges such cases pose, given the divergent interests at stake, and to suggest some potential models for children's rights and human rights compliant law, policy and practice. ${ }^{1}$

1 This article was finalised and accepted for publication in July 2020 - the law and literature is current as of that date. 
The issue of capital punishment for children (Linde, 2011; James and Cecil, 2003-2004) and the sentence of juvenile life without parole (Yun, 2010; O'Brien and Fitz-Gibbon, 2016) have occupied human rights scholars. As is discussed below, both sentences are clearly contrary to established human rights norms. Yet, the sentence of life with the availability of parole, or long fixed sentences, also involve the child being detained for long periods, often equating or exceeding the term of their own life to date. The recent United Nations Global Study on Children Deprived of Liberty shows that the use of the life sentence remains prevalent across jurisdictions, particularly in the common law world (Nowak, 2019: 290-291). Child Rights International Network (CRIN) (2015a: 5) report that 73 states allow life imprisonment for children, while Van Zyl Smit et al. (2019: 14) find that most Commonwealth countries follow suit. The UN Global Study on Children Deprived of Liberty reports that in jurisdictions where life imprisonment is not permitted for children, maximum custodial sentences for children range from 3 to 50 years. The average maximum sentence is 13.3 years, while the median average lies at 12 years (Nowak, 2019: 9o).

Tables 1 and 2 (derived from Lynch, 2018a) which follow give a simplified overview of common law systems' approach to the sentencing of young offenders for murder.

A first observation is that the common law jurisdictions surveyed have low minimum ages of criminal responsibility (MACR). These may be mitigated in part by the doli incapax principle, and restrictions on the prosecution and sentencing of younger children. However, some jurisdictions have exceptions to restrictions on prosecution for murder charges (see New Zealand's Oranga Tamariki Act, s. 272; Ireland's Children Act 20o1, s. 52(2)). Most jurisdictions transfer the child's case to the adult court.

This figure shows that the indeterminate sentence is regularly used for children. In England and Wales, the sentence of life is mandatory for murder and includes a minimum period of detention, beginning at 12 years for children. Several decisions such as $R v$ Markham and Edwards (2017) and $R v$ McGill, Hewitt and Hewitt (2017) have held that the mandatory indeterminate sentence is not contrary to the European Convention on Human Rights, because of the discretion available to set the minimum term. Similarly, in New Zealand, the life sentence is presumptive for murder, with no exception for children. The minimum term starts at 10 years, but children have received minimum terms up to 17 years (Lynch, 2018b). Some jurisdictions have limited statutory exceptions for children, but only the Australian Capital Territory explicitly prohibits the life sentence. Canadian federal law fixes the maximum sentence for 
TABLE 1 Age parameters and jurisdiction in a selection of common-law jurisdictions

\begin{tabular}{|c|c|c|c|}
\hline Jurisdiction & $\begin{array}{l}\text { Age of Criminal } \\
\text { Responsibility }^{1}\end{array}$ & $\begin{array}{c}\text { Age of Penal } \\
\text { Majority }^{2}\end{array}$ & $\begin{array}{l}\text { Jurisdiction for } \\
\text { Murder Cases }\end{array}$ \\
\hline New Zealand & 10 & 18 & High Court \\
\hline England and Wales & 10 & 18 & Crown Court \\
\hline Republic of Ireland & 10 & 18 & $\begin{array}{l}\text { Central Criminal } \\
\text { Court }\end{array}$ \\
\hline Scotland & $8^{3}$ & 16 & $\begin{array}{l}\text { High Court of } \\
\text { Justiciary }\end{array}$ \\
\hline Canada & 12 & 18 & Youth Court ${ }^{4}$ \\
\hline $\mathrm{ACT}$ & 10 & 18 & $\begin{array}{l}\text { Supreme Court of } \\
\text { the } \mathrm{ACT}^{5}\end{array}$ \\
\hline New South Wales & 10 & 18 & $\begin{array}{l}\text { Supreme Court of } \\
\text { NSW }\end{array}$ \\
\hline Queensland & 10 & 18 & $\begin{array}{l}\text { Supreme Court of } \\
\text { Queensland }\end{array}$ \\
\hline South Australia & 10 & 18 & $\begin{array}{l}\text { Supreme Court of } \\
\text { South Australia }\end{array}$ \\
\hline Tasmania & 10 & 18 & $\begin{array}{l}\text { Supreme Court of } \\
\text { Tasmania }\end{array}$ \\
\hline Victoria & 10 & 18 & $\begin{array}{l}\text { Supreme Court of } \\
\text { Victoria }\end{array}$ \\
\hline Western Australia & 10 & 18 & $\begin{array}{l}\text { Children's Court } \\
\text { of Western } \\
\text { Australia }^{6}\end{array}$ \\
\hline Northern Territory & 10 & 18 & Supreme Court \\
\hline
\end{tabular}

1 Minimum age from which a child may be held liable for a criminal offence.

2 Age at which a child normally "ages" out of the youth justice system.

3 While the official age remains 8 years, the minimum age for prosecution is 12.

4 The Youth Court can impose a full adult sentence upon an application by the Attorney-General.

5 The Children's Court does not have jurisdiction over offences punishable by life imprisonment. Manslaughter only carries a 2o-year maximum sentence.

6 Children can be tried as adults in the Supreme Court in some circumstances, such as where there is a co-accused who is an adult, or where the accused has subsequently turned 18. 
TABLE 2 Sentencing parameters for children convicted of murder in a selection of commonlaw jurisdictions

\begin{tabular}{|c|c|c|}
\hline Jurisdiction & $\begin{array}{l}\text { General Sentence for } \\
\text { Murder }^{7}\end{array}$ & $\begin{array}{l}\text { Statutory Exceptions }{ }^{8} \\
\text { for Children }\end{array}$ \\
\hline New Zealand & $\begin{array}{l}\text { Presumption of life unless } \\
\text { manifestly unjust }\end{array}$ & $\begin{array}{l}\text { Life without parole } \\
\text { prohibited }\end{array}$ \\
\hline England and Wales & $\begin{array}{l}\text { Mandatory life } \\
\text { imprisonment }\end{array}$ & $\begin{array}{l}\text { Shorter minimum } \\
\text { non-parole periods }\end{array}$ \\
\hline Republic of Ireland & $\begin{array}{l}\text { Mandatory life } \\
\text { imprisonment }\end{array}$ & Not mandatory. ${ }^{9}$ \\
\hline Scotland & $\begin{array}{l}\text { Mandatory life } \\
\text { imprisonment }\end{array}$ & \\
\hline Canada & $\begin{array}{l}\text { Mandatory life } \\
\text { Imprisonment }\end{array}$ & $\begin{array}{l}\text { Maximum } 10 \text { years } 1 \text { st } \\
\text { degree murder } 7 \text { years } \\
\text { 2nd degree murder }{ }^{10}\end{array}$ \\
\hline ACT & $\begin{array}{l}\text { Life is a discretionary } \\
\text { maximum }\end{array}$ & $\begin{array}{l}\text { Life imprisonment } \\
\text { prohibited for children }\end{array}$ \\
\hline New South Wales & $\begin{array}{l}\text { Life is a discretionary } \\
\text { Maximum }\end{array}$ & $\begin{array}{l}\text { Age should be relevant in } \\
\text { exercise of discretion }\end{array}$ \\
\hline Queensland & $\begin{array}{l}\text { Mandatory life } \\
\text { imprisonment }\end{array}$ & $\begin{array}{l}\text { Life imprisonment is not } \\
\text { mandatory for murder }{ }^{11}\end{array}$ \\
\hline South Australia & $\begin{array}{l}\text { Mandatory life } \\
\text { imprisonment }\end{array}$ & $\begin{array}{l}\text { Discretion in non-parole } \\
\text { period }\end{array}$ \\
\hline Tasmania & $\begin{array}{l}\text { Life is a discretionary } \\
\text { maximum }\end{array}$ & $\begin{array}{l}\text { Age should be relevant in } \\
\text { exercise of discretion }\end{array}$ \\
\hline Victoria & $\begin{array}{l}\text { Life is a discretionary } \\
\text { maximum }\end{array}$ & $\begin{array}{l}\text { Age should be relevant in } \\
\text { exercise of discretion }{ }^{12}\end{array}$ \\
\hline Western Australia & $\begin{array}{l}\text { Presumptive sentence of } \\
\text { life imprisonment }{ }^{13}\end{array}$ & $\begin{array}{l}\text { Life is a discretionary } \\
\text { maximum for murder }\end{array}$ \\
\hline
\end{tabular}


TABLE 2 Sentencing parameters for children convicted of murder in a selection of commonlaw jurisdictions (cont.)

\begin{tabular}{lll} 
Jurisdiction & $\begin{array}{l}\text { General Sentence for } \\
\text { Murder }^{7}\end{array}$ & $\begin{array}{l}\text { Statutory Exceptions } \\
\text { for Children }\end{array}$ \\
\hline Northern Territory & $\begin{array}{l}\text { Mandatory life } \\
\text { imprisonment }\end{array}$ & $\begin{array}{l}\text { May sentence child to } \\
\text { lesser term }\end{array}$ \\
\hline
\end{tabular}

7 This column indicates the general sentence upon conviction for murder.

8 This column indicates whether there are statutory exemptions for those who would normally be subject to the youth justice system.

9 The situation in the Republic of Ireland can best be described as unclear. The Criminal Justice Act 199o provides that the life sentence is mandatory for all offenders for murder and makes no exception for youth. The Children Act 2001 contains no express prohibition of the life sentence. In late 2019, a 14-year old boy was given life in detention with the sentence to be reviewed after 12 years, while his co-offender received a fixed sentence. This suggests that life is not mandatory for children.

10 The Attorney-General can request that the Youth Court gives a full adult sentence of life if the offender was over 14 at the time of offending.

11 There is a high threshold for giving a life sentence to youth offenders. It must have been a 'particularly heinous offence'.

12 Standard sentence of 25 years is not applicable to those aged less than 18.

13 Life sentence may not be given where it would be clearly unjust and the offender is unlikely to pose a threat.

children, but the Attorney General may make an application for the child to be sentenced as an adult.

Before extending the comparative analysis to considering the sentences available in a sample of European jurisdictions, we will consider the human rights framework for children in conflict with the law.

\section{The Human Rights Framework for Children in Conflict with the Law}

A vast body of both general human rights standards and child specific standards have been developed to regulate responses to crimes committed by children, internationally as well as regionally (Liefaard, 2008; Goldson and Kilkelly, 2013; Liefaard, 2015). The almost universally ratified and legally binding United Nations Convention on the Rights of the Child (CRC) can be considered the most important international children's rights treaty, containing several rights and standards specifically designed to protect children in the justice system (cf. Arts. 40 and 37). In General Comment No. 24 (2019a), which recently replaced General Comment No. 10 (2007), the Committee on the Rights of the 
Child (the Committee) provides updated guidance on a CRC-compliant child justice system. We refer to these instruments in this piece as the "children's rights framework" or "children's rights standards". We also note that children are rights-bearers under the general human rights framework, and that in some places we will refer to the general human rights standards in relation to other parties' rights (such as those of victims).

The general purposes of (Western) criminal justice systems are traditionally considered to be retribution, incapacitation, specific deterrence, general deterrence and rehabilitation (Packer, 1968; Canton, 2017). In contrast, international children's rights standards require a child-centered youth justice framework, in which the child's best interests should always be a primary consideration (Art. 3 (1) CRC; cf. General Comment No. 14 (2013)). According to the Committee (2013: para. 28), 'the traditional objectives of criminal justice, such as repression/retribution, must give way to rehabilitation and restorative justice objectives in dealing with child offenders'. Overall, the framework for children in conflict with the law is built on four pillars: (1) humane treatment; (2) child-specific treatment; (3) fair treatment; and (4) treatment aimed at reintegration in society (Van den Brink, 2019a). This framework is applicable to all children in conflict with the law, including children who are accused or convicted of very serious offences such as murder.

The fundamental principle of humane treatment lies at the heart of the children's rights framework on youth justice, acknowledging children in conflict with the law as human beings with human rights. Children should be treated with humanity and respect for their inherent dignity and worth, also when they allegedly committed a severe criminal offence (Art. 40 (1) CRC) and/or when they are deprived of their liberty (Art. 37(c) CRC). This principle also implies an absolute prohibition of torture or other cruel, inhuman or degrading treatment or punishment, including a ban on the imposition of capital punishment or life imprisonment without possibility of release for offences committed by children (Art. 37(a) CRC). With reference to Articles 4O(1) CRC and 37(a) CRC, the Committee (2019a: para. 81) explicitly recommends that, 'States parties abolish all forms of life imprisonment, including indeterminate sentences, for all offences committed by persons who were below the age of 18 at the time of commission of the offence'.

The principle of child-specific treatment stems from the notion that children are fundamentally different from adults, not only physically, but also cognitively, emotionally and psychosocially. This notion has been strengthened by an increasing scientific body of knowledge on child and adolescent development (cf. Grisso and Schwartz, 2000; Grisso et al., 2003; Steinberg and Scott, 2003; Scott and Steinberg, 2009; Rap, 2013; Steinberg, 2017), 
which has been embraced by the Committee in its new General Comment No. 24. The Committee (2019a, para. 22) notes that, 'documented evidence in the fields of child development and neuroscience indicates that maturity and the capacity for abstract reasoning is still evolving in children ... due to the fact that their frontal cortex is still developing'. Subsequently, the Committee (2019a, para. 22) highlights that, 'adolescence is a unique defining stage of human development characterized by rapid brain development, and this affects risk-taking, certain kinds of decision-making and the ability to control impulses'. Against this background, children in conflict with the law must be treated in accordance with their age, needs and evolving capacities (Arts. 4O(1) and (4) CRC and Art. 37(c) CRC). This presupposes that States must provide for a youth justice system with specific laws, procedures, interventions and services that are suitable for children (Art. 40 (3) and (4) CRC) and a minimum age of criminal responsibility (Art. 4O(3) (a) CRC), which according to the Committee (2019a: para. 22) should not be lower than 14. Youth justice systems must also contain an upper age limit, which should safeguard that no children - i.e. persons below the age of 18 at the time of the offence - can be tried or sentenced under the adult criminal justice system.

The principle of fair treatment presupposes that children in conflict with the law have the right to a fair trial and must be protected against unlawful, arbitrary, discriminatory or manifestly disproportionate State intervention. This means that child suspects have procedural rights, such as the right to be tried by an independent and impartial authority, the right to legal aid, the right to have their privacy respected and to be tried behind closed doors, and the right to participate effectively in their proceedings (Art. 40 (2) CRC). Youth justice interventions must have a basis in national law and be free from arbitrariness - certainly when it comes to deprivation of liberty (Art. 37(b) CRC) - and must be proportionate to the seriousness of the offence and the culpability of the child (Art. 40 (4) CRC).

The principle of treatment aimed at reintegration reflects the ultimate objective of a children's rights compliant youth justice system (Article 40 (1) CRC). This reintegration objective entails, among other things, that deprivation of liberty of children shall be used only as a measure of last resort and for the shortest appropriate period of time (Art. 37(b) CRC) and that interventions must be appropriate to the specific circumstances and needs of the child (Art. 40 (4) CRC). Moreover, the reintegration objective also implies avoiding stigmatisation of the child (cf. Committee, 2019a: paras. 66-71), inter alia by protecting the child's privacy (e.g. through hearings behind closed doors and non-disclosure of the child's identity) and by limiting the negative consequences of 
a conviction for the child's future life chances (e.g. by expunging criminal records at age 18). Wherever possible, children should even be kept entirely outside of the formal youth justice system, for example by using informal remedies or by diverting cases to civil child protection services, provided that the safeguards for a fair trial are not neglected (Art. 40 (3)(b) CRC). The rationale behind this pillar is that achieving successful reintegration, meaning that the child assumes a constructive role in society, serves the interests of both the child and society.

These four pillars establish the basis of a principled youth justice system that is in compliance with international children's rights standards. But can these principles still be upheld in practice when a child commits homicide, taking the life of another human being and sparking massive public outcry and public safety concerns?

In the next section, we consider the prevailing current approach across European jurisdictions, before turning a normative lens on the more difficult question of what a children's rights compliant approach to murder looks like in practice.

\section{$4 \quad$ Sentencing Across a Selection of European Jurisdictions}

\section{1 'Better in Europe'? - Purpose of the Survey}

Building further on Lynch's (2018a) comparative analysis of common law jurisdictions, we extended the survey research to discover whether European civil law jurisdictions might offer examples of more tolerant and child-centred responses which would provide scalable models of children's rights compliant accountability (see Pruin and Dunkel, 2015). It can at least be said that European jurisdictions generally prohibit the use of the life sentence for those aged less than 18 (CRIN, 2015b). A report (CRIN, 2015b) stated that of the 28 European Union states (then including the United Kingdom), 22 had explictly prohibited life imprisonment for persons aged less than 18, or placed a clear limit on the period of detention which falls short of life imprisonment. ${ }^{2}$ Apart

2 Nevertheless, it should be noted that our initial literature review demonstrates that the selected European jurisdictions (see para. 4.3), had also been the subject of criticism by the UN Committee on the Rights of the Child, amongst others, about the treatment of children as adults under the criminal justice system (Belgium, Denmark, the Netherlands, Norway). The Committee has also articulated concerns about lengthy pre-trial detention periods and custodial sentences for children (Denmark, the Netherlands, Sweden) and about deprivation of liberty not being used as a last resort (Germany, the Netherlands, Sweden). See UN Committee on the Rights of the Child, 2014; 2015a; 2015b; 2017; 2018; 2019b. 
from Cyprus and France, it is the common law countries (jurisdictions of the United Kingdom and Ireland) which retain forms of life imprisonment.

\subsection{Definition of Murder}

For the purpose of this research, we use the term "murder" as the equivalent to intentional homicide. The United Nations Global Study on Homicide (2019: 7) defines "intentional homicide" as: "unlawful death inflicted upon a person with the intent to cause death or serious injury'.

\subsection{Selection of Jurisdictions}

We selected a range of civil law jurisdictions in North-Western Europe: Belgium, Denmark, Germany, the Netherlands, Norway and Sweden. These are not completely indicative of the wider European context but are traditionally considered to be amongst the most tolerant in the Western world (Lappi-Seppälä, 2015; Goldson, 2018). On a practical note, we have selected jurisdictions as to which we could obtain accurate information in English or Dutch and/or had contacts with experts who could provide and check the information.

\subsection{Methodology}

We gathered a large range of material around the trial and sentencing of children for murder in the selected jurisdictions. The survey methodology we used was of structured questions with information obtained from review of primary sources such as legislation, government policy documents, documents from human rights bodies and case law, as well as literature. ${ }^{3}$ The survey results were peer-reviewed by colleagues in the various jurisdictions (but any errors remain our own).

The tables below present generalised forms of information about the national legal frameworks of sentencing children for murder, which may not entirely represent the details of the systems and the common usage of the law, particularly the prevalence of the use of the maximum penalty (Lynch, 2018a), as judicial discretion may operate to minimise the punitiveness of legislated sentences (Lynch, 2019). The presented comparative analysis is thus not fully capable of capturing the distinctive legal, institutional and cultural underpinnings and practical realities of youth sentencing in the selected jurisdictions. Yet, as an explorative study, the presented analysis can nevertheless provide valuable cross-national insights into youth sentencing frameworks for murder, which can be used to inform internal debates within jurisdictions and further

3 Inter alia: Dünkel, 2015; Lappi-Seppälä, 2015; Holmboe, 2017; Persson, 2017; Goldson, 2018; Nowak, 2019. 
research (cf. Nelken, 2010). Besides, we use a case study (the Netherlands) to give a more detailed illustration of how youth sentencing in one of the selected European civil law jurisdictions operates in practice. For the purpose of this paper, the key survey questions are:

1) What is the age at which a child can be held liable for murder?

2) Are children accused of murder dealt with in a specialised youth court or in an adult court?

3) What is the maximum sentence available for children convicted of murder?

4) Is an adult sentence available for children convicted of murder?

The next sections will disclose the survey findings for the selected European civil law jurisdictions and compare these results with the previous survey findings for the common-law jurisdictions.

\subsection{Relevant Ages}

Table 3 shows that the European civil law jurisdictions surveyed had comparatively higher MACR than common law jurisdictions, despite the fact that not all civil-law jurisdictions live up to the recommendation of the Committee (2019a, para. 22) to fix the MACR at 14 or higher. Yet, all were compliant with the definition of child as expressed in the Convention, having the general age

TABLE 3 Age parameters in the child justice systems of a selection of European civil law jurisdictions

\begin{tabular}{lllcc}
\hline Jurisdiction & $\begin{array}{l}\text { General Minimum } \\
\text { Age of } \\
\text { Criminal } \\
\text { Responsibility }{ }^{14}\end{array}$ & $\begin{array}{l}\text { Different / } \\
\text { specific age } \\
\text { parameters for } \\
\text { prosecution of } \\
\text { murder? }\end{array}$ & $\begin{array}{c}\text { General age } \\
\text { of penal } \\
\text { majority }\end{array}$ & $\begin{array}{c}\text { Upper age } \\
\text { limit for use } \\
\text { of youth } \\
\text { sentences }\end{array}$ \\
\hline Netherlands & 12 & No & 18 & 23 \\
Germany & 14 & No & 18 & 21 \\
Belgium & 12 or undefined ${ }^{16}$ & No & 18 & $20 / 23$ \\
Sweden & 15 & No & 18 & 21 \\
Denmark & 15 & No & 18 & 21 \\
Norway & 15 & No & 18 & 18 \\
\hline
\end{tabular}

14 Minimum age from which a child may be held liable for a criminal offence

15 The age at which a child ages out of the child justice system. In most jurisdictions this age refers to the age at the time of committing the offence.

1612 (Flanders) or undefined. Belgium is a federal state and each community may regulate the judicial reaction to juvenile delinquency. 
TABLE 4 Jurisdiction of court for murder cases in a selection of European civil law jurisdictions

$\begin{array}{lll}\text { Jurisdiction } & \begin{array}{l}\text { Jurisdiction for murder cases } \\ \text { with child defendants }\end{array} & \begin{array}{l}\text { Transfer of trial } \\ \text { to adult court } \\ \text { permitted? }\end{array}\end{array}$

\begin{tabular}{lll}
\hline Netherlands & Youth/juvenile court & No \\
Germany & Youth/juvenile court & No \\
Belgium & Youth/juvenile court & $\begin{array}{l}16 / 17 \text {-year olds may } \\
\text { be transferred to } \\
\text { adult court }\end{array}$ \\
& & - \\
Sweden & Criminal court - no youth court & - \\
Denmark & Criminal court - no youth court & - \\
Norway & Criminal court - no youth court & -
\end{tabular}

of penal majority of 18 , and the majority also extend elements of the youth justice system to young adult offenders, as recommended by the Committee (2019a, paras. 29-32; see also Schmidt, Rap and Liefaard, 2020).

\subsection{Jurisdiction for Resolution of the Offence}

A point of interest is that the Scandinavian countries in the sample do not have separate youth courts, which is not in compliance with the Convention (Article 4O(3) CRC). The rest resolve charges through a youth court, though transfer to the adult court is permitted for 16/17-year olds in Belgium (see table 4).

\subsection{Sentences Available}

As table 5 illustrates, there is a wide variety of sentences available for children who commit murder. The Netherlands and Belgium seem to have rather lenient maximum sentences in the youth justice system but allow 16- and 17-year olds to be sentenced as adults. Sweden, Denmark and Norway do not have separate, comprehensive youth sentencing legislation. There, the maximum sentences for youth are mitigated prison sentences. Germany is the only selected jurisdiction that does not allow imposing an (adult) prison sentence for children. The sentence of life imprisonment for children is prohibited in all jurisdictions, but preventive detention is available in some jurisdictions under exceptional circumstances. Except for the Netherlands, (adult) prison sentences imposed on children in the selected jurisdictions are in principle served in a separate wing or facility until they reach at least the age of 18 . 
TABLE 5 Sentences available for children convicted of murder in a selection of European civil law jurisdictions

\begin{tabular}{|c|c|c|}
\hline Jurisdiction & $\begin{array}{l}\text { Maximum sentence } \\
\text { available in child } \\
\text { justice system }\end{array}$ & $\begin{array}{l}\text { Adult sentence } \\
\text { available for } \\
\text { children? }\end{array}$ \\
\hline Netherlands & $\begin{array}{l}1 \text { or } 2 \text { years in youth } \\
\text { detention plus } 7 \text { years } \\
\text { youth closed } \\
\text { treatment order }{ }^{17}\end{array}$ & $\begin{array}{l}\text { 16/17-year olds: max } \\
30 \text { years prison } \\
\text { sentence plus adult } \\
\text { closed treatment } \\
\text { order }^{18}\end{array}$ \\
\hline Germany & $\begin{array}{l}10 \text { years custodial } \\
\text { youth penalty plus, in } \\
\text { exceptional } \\
\text { circumstances, } \\
\text { post-sentence } \\
\text { preventive detention }{ }^{19}\end{array}$ & No \\
\hline Belgium & $\begin{array}{l}7 \text { years youth closed } \\
\text { care order }^{20}\end{array}$ & $\begin{array}{l}\text { 16/17-year olds: max } \\
30 \text { years prison } \\
\text { sentence }^{21}\end{array}$ \\
\hline Sweden & $\begin{array}{l}14 \text { years prison } \\
\text { sentence }^{22}\end{array}$ & $\begin{array}{l}\text { Maximum sentence } \\
\text { for youth is equivalent } \\
\text { to a mitigated adult } \\
\text { prison sentence } \\
\text { (max } 14 \text { years). }\end{array}$ \\
\hline Denmark & $\begin{array}{l}16 \text { years or } 20 \text { years } \\
\text { prison sentence }\end{array}$ & $\begin{array}{l}\text { Maximum sentence } \\
\text { for youth is equal to } \\
\text { the maximum fixed } \\
\text { term adult prison } \\
\text { sentence ( } \max 16 / 20 \\
\text { years) }\end{array}$ \\
\hline
\end{tabular}


TABLE 5 Sentences available for children convicted of murder in a selection of European civil law jurisdictions (cont.)

\begin{tabular}{llll} 
Jurisdiction & $\begin{array}{l}\text { Maximum sentence } \\
\text { available in child } \\
\text { justice system }\end{array}$ & $\begin{array}{l}\text { Adult sentence } \\
\text { available for } \\
\text { children? }\end{array}$ & $\begin{array}{l}\text { Life sentence } \\
\text { available for } \\
\text { children? }\end{array}$ \\
\hline Norway & $\begin{array}{l}\text { 15 years prison } \\
\text { sentence plus, in } \\
\text { exceptional circum- } \\
\text { stances, preventive } \\
\text { detention }\end{array}$ & $\begin{array}{l}\text { Maximum sentence } \\
\text { for youth is equivalent } \\
\text { to a mitigated adult } \\
\end{array}$ & $\begin{array}{l}\text { prison sentence (max } \\
15 \text { years); preventive } \\
\text { detention available for } \\
\text { adults and youth }\end{array}$ \\
& &
\end{tabular}

17 Articles. 77 i and 77s Dutch Criminal Code. Youth closed treatment order can be converted into an adult closed treatment order; potentially life long. See case study in section 4.8.

18 Article 77b Dutch Criminal Code: 16/17-year olds sentenced as adults: max. 30-year prison sentence + adult closed treatment order (2 years, possibly extended, potentially life long). See case study in section 4.8.

19 German Youth Courts Law (Jugendgerichtsgesetz, JGG) s. 18 and s. 7. Preventive detention may be ordered after a sentence of at least seven years' youth penalty if the nature of the offence and the development of the person means that they are highly likely to commit criminal offences of the same severe nature again.

20 Article 29 $(2)\left(8^{\circ}\right)$ Flemish Youth Delinquency Decree (2019).

21 Article 57bis Flemish Youth Protection Law/Art. 38 Flemish Youth Delinquency Decree (2019).

22 Swedish Penal Code ch. 29 s. 7.

23 Danish Criminal Code s. 33.

24 Norwegian Criminal Code ch. 6 s. 33 and ch 7 s 4o. Preventive detention may not be imposed for children unless altogether extraordinary circumstances apply. The duration of preventive detention should normally not exceed 10 years and no longer than 15 years. On application the period may be extended by up to 5 years at a time.

\subsection{A Case Study - the Netherlands}

Whilst the high-level comparative analysis just presented is useful in illustrating trends, it may not uncover the true operation of the system and its effects on children and their rights. Therefore, we consider a case study from the Netherlands, a traditionally "tolerant" civil law jurisdiction where the issue of sentencing children who kill is highly topical and currently very much under public and political scrutiny. At first glance, the Netherlands has a comparatively short maximum custodial sentence available, and most children are dealt with in the youth justice system. But further examination reveals that there are still potentially punitive orders available to be used for children.

The youth justice system in the Netherlands applies in principle to children who have reached the age of 12 , but not yet the age of 18 at the time of the offence. 
The system can be characterised as a mixture between a "justice-oriented" system and a "welfare-oriented" system (Uit Beijerse and Van Swaaningen, 20o6; Van den Brink, 2015; Weijers, 2014). The youth justice system holds children criminally responsible for their actions, provides them with fair trial rights and is governed by traditional criminal justice principles, such as legality, proportionality and the presumption of innocence. At the same time, the youth justice system strongly aims at education and reintegration of young offenders and prevention of recidivism, through child-specific procedural rules in a specialised youth court, tailored sentences and the involvement of child welfare professionals, such as professionals from the child protection agency (Raad voor de Kinderbescherming), youth probation (jeugdreclassering), and youth custodial institutions (justitiële jeugdinrichtingen) (Van den Brink, 2019b).

The maximum custodial sentence for a 12- to 15-year old who commits murder is one year of youth detention and for a 16- or 17-year old two years of youth detention. This contrasts starkly with the long sentences that the same offence would attract in a typical common law jurisdiction. Nonetheless, another option for the Court is to (also) impose a closed treatment order for youth (PIJ-maatregel), which is served in the same secure youth custodial institution (albeit with more intensive individual therapy and treatment). The closed treatment order can be imposed for children who are convicted of a severe offence, committed under the influence of a mental disorder or a distorted development that requires treatment (as diagnosed by a psychiatrist and a psychologist), if this order is necessary for public safety and for the positive development of the child. This closed treatment order is initially imposed for three years (with the last year being conditional), but can be extended various times by the court, if deemed necessary based on the risk to public safety and the development of the child. The maximum length of the closed treatment order for youth is seven years (with the last year conditional). However, if the child or young person is still considered a high risk to public safety after almost six years of closed treatment (i.e. just before the youth measure reaches the maximum custodial term and ends conditionally), the prosecutor can request the court to convert the closed treatment order for youth into a closed treatment order for adults (твS met dwangverpleging). The law that enables this conversion entered into force on 1 April 2014 and immediately sparked criticism from the UN Committee on the Rights of the Child (2015a). Nevertheless, the first conversion of a youth closed treatment order into an adult closed treatment order has become a reality on 30 July 2021, by order of the District Court in Utrecht (ECLI:NL:RBMNE:2O21:4111).

For 16- and 17-year olds, the law also allows a court to sentence them as if they are adults, when the Court deems this appropriate on the basis of the severity of the offence, the personality of the child or the circumstances of 
the case (Art. 77b (1) Criminal Code). In that case, the maximum custodial sentence that can be imposed is a 30-year prison sentence served in an adult prison. The imposition of life imprisonment is explicitly banned for persons under the age of 18 at the time of the offence (Art. $77 \mathrm{~b}$ (2) CC). Nonetheless, the court can also directly impose an adult closed treatment order $(T B S)$ to 16- and 17-year-olds, which is served in a secure treatment facility for adults. This adult closed treatment order can be imposed initially for a period of two years but can be extended by the court every one or two years based on public safety grounds. Despite the periodic reviews of the necessity to extend the order, the potentially limitless extensions of the adult closed treatment order can mean that the person concerned stays in a closed facility for the rest of his or her life. Although sentencing 16- and 17-year olds as adults is an exception and does not happen very often (between 0.5 per cent and 3 per cent of all youth court cases involving 16- or 17-year olds, according to Van der Laan et al. (2016)), the Netherlands has been criticised for this practice for years now, inter alia by the UN Committee on the Rights of the Child (2009; 2015a).

Another group also criticises law and practice in the Netherlands, but from a different perspective, namely that the sentences available are too lenient. This is clearly illustrated by a recent case involving the killing of a 14-year old female victim by a 16-year old boy (ECLI:NL: RBMNE:2018:3274), which sparked massive outcry. The boy was convicted and sentenced for intentional manslaughter by the Youth Chamber of the District Court in Utrecht. In its verdict, the Court explained that it had seriously considered sentencing the now 17-year old boy as an adult, given the severity of the offence. Nevertheless, the Court decided to use the youth sentencing framework, primarily because the psychiatric and psychological reports indicated that, given the boy's personal problems and developmental level, a lengthy closed treatment in a youth custodial institution would give the highest chances of successful rehabilitation and prevention of future reoffending. The end sentence was the maximum custodial sentence under the youth sentencing framework, which consists of two years of youth detention and a youth closed treatment order of three years (of which the last year conditional). Because the boy spent almost a year in pre-trial detention (which counts as "time served"), he will be eligible for conditional release within three years after his conviction. The court emphasised in its verdict, however, that the imposed closed treatment order can be extended up until seven years and, if necessary, even be converted into an adult closed treatment order.

Shortly after the verdict, the parents of the 14-year-old victim expressed their discontent about the shortness of sentences for youth who commit 
murder or intentional manslaughter. Together with other parents whose child had been killed by a teenager in the past, the parents of the 14-year old victim started a petition to raise the sentences for children who commit murder in Dutch law. The victims' parents argue that the maximum length of the youth detention order, which supposes to function as a proportionate punishment, does not reflect the severity of the offence, even if the lesser accountability of the young offender is taken into account. This petition has been signed by 90,00o people and was offered to the Minister of Legal Protection in September 2019. The petition has sparked ongoing debates in the Dutch Parliament about raising the sentences for children. In response to that, the Minister of Legal Protection commissioned a European comparative study on sentencing practices for youth in severe cases (see Asscher et al., 2020), which aims to help the Minister and Parliament to make informed decisions about potentially raising the sentences for youth in the Netherlands (Parliamentary Papers II 2019-2020, 35 285, 3).

Overall, this case study illustrates that justice systems in European civil law jurisdictions, despite their image of being more tolerant and child-friendly than most common law jurisdictions, may still allow for lengthy and adult(like) sentences for children who commit very serious offences. It also demonstrates the precariousness of sentence mitigation and age-appropriate measures for children where political and societal pressures for change occur (cf. O'Brien and Fitz-Gibbon, 2018). Given the lack of a fully children's rights and human rights compliant model in the surveyed jurisdictions, in the next sections we consider what such a model might look like, particularly in properly recognising the interests and rights of victims and the public.

Where severe crimes are committed by children, several sets of rights and interests are at stake; not only the child's, but those of the victims (this term includes close relatives of murder victims) and the wider public interest. The recognition, and balancing, of these interests is well-documented in general (adult) criminal justice and sentencing literature (cf. Canton, 2017). The children's rights and human rights framework also recognises the legitimacy of the interests of victims and the public (UN Committee on the Rights of the Child, 2019a: para. 76), though this aspect receives remarkably little attention in the child justice literature (Lynch 2018a; Lynch 2018b; Lynch 2018c; Van den Brink, 2019b). This section explores what the international children's rights 
and human rights framework requires when it comes to the interests of victims and the wider public in cases of child-perpetrated murder.

\subsection{Public Safety}

The Committee (2019a: para. 3) recognises that the preservation of public safety is a legitimate aim of the child justice system. The European Court of Human Rights ("ECtHR") also acknowledges that public safety can be a legitimate reason for restricting a child's personal liberty or freedom of movement in case he allegedly committed a severe offence, such as homicide (cf. J.M. v. Denmark, 2012). In fact, according to ECtHR case law, States have a positive human rights obligation to protect the lives and well-being of their citizens (Akandji-Kombe, 2007). The positive obligation under the right to life ex Article 2(1) European Convention of Human Rights ("ECHR") does not only imply that the State should, 'refrain from the intentional and unlawful taking of life, but also to take appropriate steps to safeguard the lives of those within its jurisdiction' (L.C.B. v. the United Kingdom, 1998: para. 36). According to the ECtHR, domestic authorities should consider it their 'primary duty to secure the right to life by putting in place effective criminal law provisions to deter the commission of offences against the person' and 'to take preventive operational measures to protect an individual whose life is at risk from the criminal acts of another individual' (Osman v. the United Kingdom, 1998: para. 115). This implies that preservation of "public safety" in murder cases could in some instances be a human rights issue as such, namely the protection of the human rights - i.e. the right to life - of individuals that are part of society. Human rights in criminal justice, as Tulkens (2011) argues, do not only have a "shield function", protecting the offender against unlawful interventions and unfair treatment, but can also have a "sword function", demanding State action against an individual who committed a severe offence and/or imposes a risk to public safety.

The question remains: what are - from a children's and human rights perspective - appropriate responses to child-perpetrated murder which also preserve public safety? The Committee (2019a: para. 3) emphasises that States parties should serve the aim of preserving public safety in a way that is consistent with their obligations to respect and implement the principles of child justice as enshrined in the CRC. According to the Committee (2019a, para. 3), 'evidence shows that the prevalence of crime committed by children tends to decrease after the adoption of systems in line with these principles'. Indeed, notwithstanding the few studies suggesting that longer lengths of detention are associated with decreased odds of recidivism among young homicide offenders (Caudill and Trulson, 2016; Trulson and Caudill, 2017), the evidence that punitive responses and (lengthy) detention sentences are harmful for children 
on multiple levels and increase the likelihood of reoffending is overwhelming (cf., inter alia, Dimitrieva et al., 2012; Aizer and Doyle, 2013; Wartna, Alberda and Verweij, 2013; Acton, 2015; Abram et al., 2017; Ryan, Abrams and Huang, 2014; Basto-Pereira, Ribeiro and Maia, 2017; Bears Augustyn and McGloin, 2017; Van Ham and Ferwerda, 2019).

When it comes to penal responses to severe offences committed by children, the Committee (2019a, para. 76) takes the following position:

Where serious offences are committed by children, measures proportionate to the circumstances of the offender and to the gravity of the offence may be considered, including considerations of the need for public safety and sanctions. Weight should be given to the child's best interests as a primary consideration as well as to the need to promote the child's reintegration into society.

The position of the Committee reflects that the CRC starts from the premise that the overall objective of reintegration of the child in youth justice (Art. 40 (1) CRC) serves both the child and society, meaning that the child's interests and the public interests should not been seen as polar opposites. Moreover, the CRC allows for deprivation of liberty of a child who has been convicted, but this must be for the shortest appropriate period of time (Art. 37(b) CRC). The appropriateness of the length of the deprivation of liberty boils down to the principle of proportionality and the overarching aim of reintegration. The penal response should be proportionate to the severity of the offence and the culpability and circumstances of the child (cf. Art. 4O (4) CRC). As to this, the Committee (2019a, paras. 2, 76 and 81) highlights that children should be considered lesser culpable than adults; a position that is supported by developmental scientific insights (Steinberg and Scott, 2003; Steinberg, 2017). This implies that a proportionate and appropriate custodial sentence for children should be significantly shorter than for adults. At the same time, the penal response should also be proportionate to the risk to public safety. This risk can be gradually diminished over time through effective treatment, rehabilitation and reintegration of the child (cf. Art. 4 O (1) CRC). In this regard, it is relevant to note that neuroscientific evidence suggests that child offending is unlikely to reflect irreparable depravity' (Steinberg, 2017: 415). In fact, research indicates that children and young people are particularly susceptible to rehabilitation and reintegration given that the vast majority of them grows out of crime, as evidenced by the well-documented "age-crime curve" associated with maturation of the brain (Steinberg, 2017). 
Incapacitation of the child may protect public safety in the short term, yet the child is likely to return into society eventually. This is equally true when the child is sentenced to life imprisonment, as the Committee (2019a: para. 81) emphasises that, 'the period to be served before consideration of parole should be substantially shorter than that for adults and should be realistic, and the possibility of parole should be regularly reconsidered' (cf. Art. 37(a) CRC and Art. 40 (1) CRC). Consequently, for preserving public safety in the long term, it is key that the child sufficiently reintegrates and is prepared for return to society. This requires that the child is not placed in a prison for adults and receives education, treatment and care, in accordance with his/her age, needs and abilities (cf. Art. 37(c) CRC and Art. 4O(1) CRC), as this is key for the child's future ability to remain free of crime and to reintegrate (Committee, 2019a, para. 92ff). This, in other words, makes "public safety" an argument supporting a children's rights compliant treatment of children who are sentenced for murder.

\subsection{Public Outcry}

A second "public interest" that should be addressed in the penal response to children who commit murder concerns the "public outcry" sparked by the offence. The justice system has an important function of communicating censure from the community to the offender (Duff, 2009), serving as a more civilised alternative to angry civilians taking justice into their own hands (Corstens, 2018). This public interest can also play a role in judicial decisions in individual cases. The ECtHR, for example, has recognised the "public sense of justice" as a relevant interest in relation to the use of pre-trial detention of a child suspect, inter alia in the case of J.M. $v$ Denmark (2012: para. 62) in which the ECtHR accepted the Danish court's reasoning that 'it would have offended the public sense of justice if the applicant [a 15-year old boy], who had been charged with rape and homicide of an eighty-five year-old lady, had been released pending completion of the mental status examinations'. From this point of view, it can be argued that the severity and societal impact of murder might justify imposing a lengthy custodial sentence when a child is convicted.

From a children's rights perspective, however, public outcry sparked by the offence (however it is measured) should not be the main determinate of the appropriate sentence. Instead, the penal response should be (UN CRC Committee, 2019a: para. 76; CF. Art. 4 O (4) CRC)

in proportion to the [child's] personal circumstances (age, lesser culpability, circumstances and needs, including, if appropriate, the mental health needs of the child), as well as to the various and particularly long-term needs of the society. 
Therefore, the Committee (2019a: paras. ${ }^{7-76}$ ) emphasises that children should be protected from harsh treatment and punishment (Art. 37(a) CRC) and that 'a strictly punitive approach is not in accordance with the leading principles for child justice spelled out in article 40 (1) of the CRC'. In this regard, O'Brien and Fitz-Gibbon (2018: 199) highlight that international children's standards on youth justice offer 'a unifying discourse that is not susceptible to the vagaries of public opinion ..., providing a common language through which academics, children's rights advocates and legal practitioners can resist the most excessive manifestations of punitive youth justice policy and practice'. Consequently, human rights and children's rights offer an important set of legally binding minimum standards that counterbalance and prevent excessively punitive and harsh responses - fueled by public outcry - to children who are accused or convicted of murder (cf. also Garland, 2013: 499).

\subsection{Justice for Victims}

Justice for victims has been placed high on the human rights agenda, internationally and regionally (Bassiouni, 2006; EU Fundamental Rights Agency, 2019). In a recent research report on human rights and victims of crime, the EU Fundamental Rights Agency (2019: 19) signals a 'new orientation of criminal justice as a means of doing justice to victims of violent crime', expressing that 'those responsible for acts amounting to serious human rights violations must be held to account for their actions'.

When it concerns children who kill, however, criminal law concepts of "responsibility" and "accountability" become particularly complex and delicate. Supported by developmental psychological research and brain science (Grisso et al., 2003; Steinberg and Scott, 2003; Scott and Steinberg, 2008; Steinberg, 2017), the children's rights framework is built on the premise that children cannot be held fully responsible and accountable under the criminal law. In fact, below a certain age children should not be held criminally responsible at all (cf. Art. 40 (3)(a) CRC). When it comes to children above the established minimum age of criminal responsibility, the child's culpability should still be considered diminished according to his age and evolving capacities (UN CRC Committee, 2019a: paras. 2 and 76), which must be considered in determining a proportionate sentence (cf. Art. 40 (4) CrC; see also: Von Hirsch, 2001). Thus, the human rights concept of "justice for the victim" as a call for holding offenders accountable for their actions cannot be used as a justification to punish children severely.

Therefore, attempts at pursuing justice for victims should not be centred solely in retribution. Besides, not all victims' families seek retribution (Van der Merwe and Skelton, 2014). There are many ways to pursue justice for victims 
that are not at the expense of an appropriate sentence for the child; for example, safeguarding the right to effective participation of the victim's family in the trial, providing them legal, financial and emotional support and access to psychological treatment and counselling. These are ways in which the justice system can show that it takes the rights and needs of victims seriously (see the UN Declaration of Basic Principles of Justice for Victims of Crime and Abuse of Power (1985); UN Ecosoc Guidelines on Justice in Matters involving Child Victims and Witnesses of Crime (2005); EU Directive on establishing minimum standards on the rights, support and protection of victims of crime (2012)).

It must also be noted that the human rights framework promotes implementation of restorative justice programmes, such as victim-offender mediation, which can be used as an alternative to or alongside the formal trial and sentencing of the child (ibid.). Although such restorative programmes are predominantly used in less serious cases, some scholars argue that victimoffender mediation or other restorative justice practices can offer suitable remedies to victims in severe cases such as homicide (Umbreit et al., 2003; Musila, 2005; Miller, 2011; Namuo, 2016). It is our view that murder cases do require a formal judicial procedure to attribute liability, but it may be appropriate for a restorative justice process to inform the decision around the appropriate outcome, or to promote reconciliation (particularly where the child offender and the victim's family are known to each other).

\section{$6 \quad$ Principles to Practice - Children's Rights Compliant Sentencing}

The preceding sections have discussed the complexity of the interests and rights that must be considered. We now move to considering what children's rights compliant models for sentencing children convicted of murder might involve. This is an area in which there is a dearth of guidance from international human rights bodies and the scholarly literature in the field of children's rights. In particular, there is little guidance or analysis of the concepts of "proportionality" and "age appropriateness".

\subsection{Individualised and Child-centric Sentencing}

Some aspects of a children's rights compliant approach to sentencing children convicted of murder are clear. Children should be sentenced proportionately in relation to the gravity of the offence and the specific circumstances of the child (Art. 4O (4) CRC), with the ultimate aim of successful reintegration of the child into society (Art. 40 (1) CRC). This calls for an individualised approach, meaning that mandatory minimum or presumptive sentences for children 
who commit murder - which exist in several common law jurisdictions such as England and Wales and New Zealand - are fundamentally non-compliant with the CRC. It is also clear that children who are convicted of murder should not be sentenced as if they are adults (Arts. 37(b) and 4O(1) and (3) CRC). Sentences for children should be different and significantly shorter than sentences that are imposed on adults for similar offences (cf. also Art. 37(b) CRC) and children should serve their custodial sentence in a facility that is appropriate for children (cf. Art. 37 (c) CRC). The Committee recommends that States ban all forms of life imprisonment for children (cf. Art. 37(a) CRC). Finally, States should set an appropriate MACR (Art. 4O(3)(a) CRC), which according to the Committee (2019a, para. 22) should not be lower than 14, in order to prevent children who are too young to be held accountable for their actions from being tried, convicted and sentenced, regardless of the severity of the offence.

\subsection{Purpose of the Sentence}

Our comparative analysis has demonstrated that though the purposes of a sentence may be conceptually distinct, the practical impact on a child may be similar. The common law countries surveyed hold fast to the idea of the guiding principle of retributive sentencing for murder, even for children, which diverges from the principles of the children's rights framework. The indeterminate sentences or long fixed sentences in prevalent use in the common law jurisdictions, such as detention at Her Majesty's Pleasure in England and Wales (cf. Stone, 2018), are said to fulfil both a purely retributive punitive element (the minimum term of imprisonment) and a risk to public safety element (when the minimum term is exhausted, public safety may be a reason for continued detention). In contrast, the closed treatment order for youth in the Netherlands is conceptually different and appears broadly aligned to the purposes in the international children's rights framework. This order is said not to be based on retribution but rather on the assessed need for (continuing) the treatment of a potentially dangerous young offender in a closed setting for the purposes of preserving public safety and contributing to a positive development and, ultimately, successful reintegration of the young person (Reef, Jeltes and Van den Brink, 2020). Yet, although it is initially imposed for a fixed term of three years, it is open to extensions (of a maximum of two years each) by the court and, after six years, to conversion into an adult closed treatment order, which is - at least in theory - open to unlimited extensions (see para. 4.8).

Although the Committee (2019a) is very critical about indeterminate custodial sentences for children and both the English and Welsh sentence of detention at Her Majesty's Pleasure and the Dutch closed treatment order can ultimately result in lifelong deprivation of liberty, it could be argued that 
the format of the Dutch treatment order is more in line with children's rights standards. When it comes to the closed treatment order, the default position is that this order ends after the fixed period of three years, unless the court deems it necessary for the protection of public safety and the development of the child to renew the order. This implies that the execution of the closed treatment order is entirely dedicated to preparing the child for a safe and sound release into society by providing treatment, education and making arrangements with services outside the closed institution. This seems to be in line with the Committee's (2019a: para. 81) recommendations that children who serve indeterminate custodial sentences should receive 'education, treatment and care aiming at his or her release, reintegration and ability to assume a constructive role in society' and with the requirement of safeguarding a 'regular review of the child's development and progress in order to decide on his or her possible release'. Nevertheless, the uncertainty for the child offender about the length of the sentence, with even the potential prospect of a lifetime in custody, makes any indeterminate sentence for a child highly controversial. Besides, as we have seen in the Dutch case study, indeterminate sentences also entail continued uncertainty and potentially stress for the victim's family about when the convicted person will be released.

\subsection{The Parameters of the Sentence}

What is less clear in the international standards is the permissible parameters of the sentence. The children's rights framework, despite its emphasis on "diversion" and non-custodial outcomes (cf. Arts. 40(3)(b), 37(b) and 40(4) CRC), seems to leave room for substantial custodial sentences for children who are found guilty of grave offences such as murder, as long as the court takes into account the child's age, lesser culpability, circumstances and needs and the sentence does not amount to strictly punitive and overly harsh treatment (cf. para. 5.2).

The Committee, in its latest General Comment No. 24 (2019), does not take the step of fixing a concrete universally appropriate upper limit on sentences for children. Also at the European level, it is accepted that the determination of proportionate and appropriate sentence lengths is ultimately a matter for the domestic legislator and/or judiciary (cf. Aleksandr Aleksandrov $v$ Russia, ECtHR 2018, para. 22). Yet, as we recommend below, international children's rights standards do indicate that States should fix a clear maximum limit for child sentences in their national law, which reflects children's diminished culpability and their susceptibility to rehabilitation and reintegration. Besides, it should be noted that the proportionality and age-appropriateness of a child custodial sentence does not only relate to the length of the sentence, but also 
to the regime, conditions, services and overall "quality of life" inside the facility where the sentence is served. ${ }^{4}$

\subsection{Punitive Sentences as a "Backstop"}

Our survey findings demonstrates that across common law and civil law jurisdictions, despite the Convention's requirement 'that all children are entitled to enjoy all of their rights, in all circumstances' (Kilkelly, 2019), adult sentences continue to be utilised, or kept available for children convicted of murder. This is also true for traditionally "tolerant" jurisdictions, such as the Netherlands.

As we have seen in the presented case study, the Netherlands seems to have quite lenient custodial sentences for children who are sentenced under the youth justice framework (i.e. one or two years of youth detention), but also allows adult sentences to be imposed to 16- and 17-year old children (i.e. up to 30 years in an adult prison). This is a trend that may be observed in other jurisdictions also. It seems that political and public acceptance of the general availability of tolerant and age appropriate sentencing options in the youth justice system continues to exist by virtue of the possibility to sentence children as adults. This "backstop" is considered appropriate for alleviating public safety concerns, satisfying a need for public outcry and providing justice for victims in a particular case (cf. Dutch Parliamentary Papers II 2018-2019, 28741, 53).

Other jurisdictions, however, take a different approach. Germany, for example, has more lengthy custodial sentencing options within its youth justice system (i.e. a ten-year custodial sentence), but no possibility to sentence children as adults (s. 18, Youth Courts Law (Jugendgerichtsgesetz, JG G); Matthews, Schiraldi and Chester, 2018). From a children's rights perspective, the latter approach seems to be preferable, as sentencing children as adults is a stark violation of the CRC (cf. Art. 37(c) CRC and Art. 4O(1) and (3) CRC). This implies that sentences for children who commit murder should be designed for children and should be part of the youth justice sentencing framework.

\subsection{Towards a Children's Rights Compliant Model}

Drawing these threads together, we argue that a human rights and children's rights compliant approach would permit a wider range of available dispositions for children who are found guilty of murder, which would include non-custodial sentences and require custodial sentences to have definite parameters. Based on the children's rights notion of "evolving capacities"

4 Cf. also Crewe's (2011; 2015; 2020) inspirational work on the notions of "depth", "weight", "tightness" and "breadth" of imprisonment, which can also be useful lenses to study children's experiences of life in a custodial facility. 
(cf. Art. 5 CRC), meaning that that the capacities and responsibilities of children generally gradually increase as they grow older, the fixed maximum lengths for youth custodial sentences require age differentiation. This implies that, generally, the maximum sentence for a 14-year old should be shorter than the maximum sentence for a 17-year old (where other factors such as any aggravating features of offence are managed). The age at the time of the offence should be determinative (i.e., not the age at the time of prosecution, trial or sentencing) and there should be judicial discretion to impose a lower sentence, based on the child's individual circumstances and capacities in accordance with his/her developmental stage. Youth sentencing schemes should not include the option to sentence children as adults. Youth custodial sentences should be served in appropriate youth custodial facilities, with a separate wing for young adults, and should from day one be fully dedicated to treatment, education and preparing the child for return into society.

Only for the most exceptional cases in which a person who committed the offence as a child has almost finished his or her custodial sentence, but evidently continues to impose a serious risk to public safety, we acknowledge the need for an option to start a separate judicial procedure to order the continuation of treatment in a closed facility after the initially imposed sentence is served. In such extreme cases, the child's or young person's right to personal liberty may be outweighed by the interest of public safety, given that this order is used only as an absolute last resort (see Ilnseher v Germany, ECtHR 2017). The court should only impose such an order when it is convinced by the evidence - provided on the basis of a thorough assessment by an independent multidisciplinary team of experts, including a psychiatrist and a psychologist (cf. the Dutch closed treatment order, par. 4.8) - that further treatment in a closed setting is required to protect the public from death or serious bodily injury. This additional order should have fixed maximum time limits and should only be renewable after thorough assessment and judicial review. In the exceptional case that this order needs to be used, the order should continue to have the principal aim of reintegration (cf. UN Human Rights Committee, 2014, para. 21).

\section{Concluding Remarks}

Globally, jurisdictions increasingly utilise diversionary, informal and restorative measures for children in conflict with the law. Nonetheless, the legal approach to children who commit serious offences, particularly murder, remains punitive in many countries, with low minimum ages and long or indeterminate 
sentences in common usage. The enquiry that sparked this paper was whether, when compared to common law jurisdictions, European civil law jurisdictions offer models of more tolerant and child-centred approach to such cases. We conclude from our survey and more in-depth case study of the Netherlands, that this hypothesis is true in some respects. Our sample of European jurisdictions have higher minimum ages of criminal responsibility, meaning that younger children are not criminally liable. Available sentences also seem to be markedly lower in European jurisdictions and life imprisonment is explicitly banned for children. However, laws allowing (adult) prison sentences for children are also widespread in Europe.

While there is considerable literature on which sentences are not in compliance with children's rights standards, there is less guidance on what a children's rights compliant approach to such cases involves, both in principle and operation. There is particularly little attention as to how the rights and interests of victims and the public should be considered when it comes to judicial responses to children who commit murder and other very serious offences. There is an urgent need for both human rights bodies and scholars to explore this further, as the case study from the Netherlands clearly illustrates that legitimate concerns and unmet needs of victims' families and the public can easily be a catalyst for more punitive approaches.

In this article, we reviewed the latest international guidance, particularly from the recent update to the General Comment on children's rights in child justice systems, as well as existing laws and practices in various jurisdictions. Based on our analyses, we distinguished key elements of a human rights compliant framework for responses to children who commit murder, including an appropriate MACR, access to justice for child suspects, victims and the general public, and proportionate and child-appropriate sentencing options within the youth justice system, as to which we gave concrete recommendations. Overall, the international children's rights framework provides guidance for sentencing children who commit murder by requiring that these sentences should (1) be specifically designed for children, (2) not be purely punitive in nature, (3) not include a mandatory minimum, (4) be considerably shorter than adult sentences for murder, (5) not be de facto a life imprisonment sentence, (6) be executed in facilities that are appropriate to the child's or young person's age, development and needs, and (7) should aim at reintegration of the child into society.

The challenge, however, is how effectively to implement these international standards into the realities of domestic youth justice systems (cf. Goldson and Kilkelly, 2013). Under international law it is acknowledged that the determination of sentences and sentence lengths is ultimately a matter for the legislator and/or the judiciary of the particular jurisdiction and the above-mentioned 
international minimum standards leave significant room for discretion. Besides, as Green's (2008) sociological comparison of a child-on-child murder case in England and a similar case in Norway strikingly shows, the (different) ways in which jurisdictions respond to cases of children who commit murder are not just legal matters, but also have dominant political, cultural and social dimensions.

Nevertheless, we hope that the comparative and holistic human rightsbased approach, as presented in this article, proves to be useful for legislators, policymakers and members of the judiciary in common law and civil law jurisdictions for making informed, rights-based decisions about sentences for children who commit murder. We also hope that this article sparks debates in the international children's rights community about the fundamental question how the rights and interests of children in conflict with the law should be balanced against the rights and interests of victims and the public, particularly in very severe cases. Finally, we hope that this article triggers further comparative and empirical research on this matter, including research on the effectiveness of different approaches, not only in terms of reoffending, but also in terms of other outcomes, such as the child's psychological and educational development and mental health, as well as research on the ways children and victims perceive the procedural fairness of the trial and the imposed sentence in such cases.

\section{Acknowledgements}

Both authors research and teach in the areas of youth justice, children's rights, criminal justice and sentencing. The authors would like to thank research assistants Stephen Woodwark and Liesbet Vercruyssen for their support, the consulted experts for participating in the survey research and the anonymous reviewers for their useful feedback on an earlier draft of this article.

\section{References}

Abram, K.M. et al., "Beyond detention: A 12-year longitudinal study of positive outcomes in delinquent youth", JAMA Pediatrics 2017 (171(2)), 123-132.

Acton, D., The impact of detention on juvenile recidivism in Montana: is the impact of detention influenced by other factors? (Montana: University of Montana, 2015). 
Aizer, A. and Doyle Jr., J.J., Juvenile incarceration, human capital and future crime: evidence from randomly-assigned judges (Cambridge, MA: National Bureau of Economic Research, 2013).

Akandji-Kombe, J.F., Positive obligations under the European convention on human rights (Human Rights Handbooks 7 , Council of Europe, 2007).

Asscher, J.J., van den Brink, Y.N., Creemers, H.E, Huls, E., van Logchum, E.K, Lynch, N. and Rap, S.E., De strafmaat voor jeugdige daders van ernstige gewelds- en zedenmisdrijven in internationaal perspectief (The Hague: Boom Juridisch, 2020).

Bassiouni, M.C., “International Recognition of Victims' Rights”, Human Rights Law Review 2006 (6(2)), 203-279.

Basto-Pereira, M., Ribeiro, S. and Maia, A., (2017). "Needs and achievements of the juvenile justice system: Insights from two empirical studies with Portuguese young adults", International Journal of Offender Therapy and Comparative Criminology 2017 $(62(7)), 1-19$.

Bears Augustyn, M. and McGloin, J.M., "Revisiting juvenile waiver: integrating the incapacitation experience", Criminology (2017). DoI: 10.1111/1745-9125.12165.

Canton, R., Why punish? An introduction to the philosophy of punishment (London: Palgrave, 2017).

Carroll, R., "Teenagers sentenced for murder of Irish 14-year-old Ana Kriégel”, The Guardian, 5 November 2019.

Caudill, J. and Trulson, C., (2016). "The hazards of premature release: recidivism outcomes of blended sentenced juvenile homicide offenders", Journal of Criminal Justice 2016 (46), 219-227.

Child Rights International Network (CRIN), Inhuman Sentencing: Life Imprisonment of Children Around the World - Research Report (2015a). Available at: https://www.crin. org/sites/default/files/life_imprisonment_children_global_o.pdf.

Child Rights International Network (CRIN), "Life Imprisonment of Children in the European Union" (2015b). Available at: https://archive.crin.org/sites/default/files/ life_in_the_eus.pdf.

Corstens, G.J.M., Het Nederlands strafprocesrecht (Deventer: Wolters Kluwer, 2018).

Crewe, B., "Depth, weight, tightness: Revisiting the pains of imprisonment", Punishment \& Society $2011(13(5)), 509-529$.

Crewe, B., "Inside the Belly of the Penal Beast: Understanding the Experience of Imprisonment", IJCJ\&SD 2015 (4(1)), 50-65.

Crewe, B., "The depth of imprisonment", Punishment \& Society (2020, forthcoming).

Dobscha, K., "Considering a Juvenile Exception to the Felony Murder Rule, Case W", Res. L. Rev. 2019 (7O(1)), 141-185.

Dmitrieva, J., Monahan, K.C., Cauffman, E. and Steinberg, L., (2012). "Arrested development: The effects of incarceration on the development of psychosocial maturity", Multilevel Approaches Toward Understanding Antisocial Behavior: Current Research and Future Directions 2012 (24(3)), 1073-1090. 
Duff, R.A., "Punishment, Retribution and Communication", in , A. Von Hirsch, , A. Ashworth and , J.V. Roberts (eds.), Principled sentencing: Readings on theory and policy. Oxford: Hart, 2009), 126-134.

Dünkel F., "Juvenile Justice and Crime Policy in Europe”, in Zimring F.E., Langer M. and Tanenhaus D.S. (eds.), Juvenile Justice in Global Perspective (New York: NYU Press, 2015), 9-62.

European Union Agency for Fundamental Rights, Victims' rights as standards of criminal justice - Justice for victims of violent crime - Part I (European Union Agency for Fundamental Rights, 2019).

European Union (2012), Directive 2012/29/EU of the European Parliament and of the Council of 25 October 2012 establishing minimum standards on the rights, support and protection of victims of crime

Garland, D., "Penality and the penal state", Criminology 2013 (51(3)), 475-517.

Goldson, B. (ed.), Juvenile justice in Europe: past, present and future (Routledge, 2018).

Goldson, B. and Kilkelly, U., "International human rights standards and child imprisonment: Potentialities and limitations", The International Journal of Children's Rights 2013 (21(2)), 345-371.

Green D.A., When Children Kill Children: Penal Populism and Political Culture (New York: Oxford University Press, 2008).

Grisso, T. and Schwartz, R.G., "Adolescents' capacities as trial defendants", in T. Grisso and R.G. Schwartz (eds.), Youth on trial. Developmental perspectives on juvenile justice (Chicago: University of Chicago Press, 2000), 67-71.

Grisso, T., Steinberg, L., Woolard, J., Cauffman, E., Scott, E., Graham, S., Lexcen, F., Reppucci, N.D. and Schwartz, R., “Juveniles' competence to stand trial:A comparison of adolescents' and adults' capacities as trial defendants", Law and human behavior $2003(27(4)), 333-363$.

Hay, C., "Mobilization through interpellation: James Bulger, juvenile crime and the construction of a moral panic", Social \& Legal Studies 1995 (4(2)), 197-223.

Holmboe, M., "Norwegian youth punishment - opportunity or trap?", Bergen Journal of Criminal Law and Criminal Justice 2017 (5(1)), 37-58

James, A. and Cecil, J., "Out of step: Juvenile death penalty in the United States", The International Journal of Children's Rights 2004 (11(3)), 291-303.

Keller, E.C., (2012), "Constitutional Sentences for Juveniles Convicted of Felony Murder in the Wake of Roper, Graham \& J.D.B.", JLC 2012 (11(2)), 297-326.

Kilkelly, U., "All Children, All Rights, In All Circumstances", in Lynch, N. (ed.), Children's Rights in Aotearoa New Zealand-Reflections on the 3oth Anniversary of the Convention on the Rights of the Child (Law Foundation/Michael \& Suzanne Borrin Foundation, Wellington, 17 December 2019). 
Kloepfer, J., "Denial of Hope: Sentencing Children to Life in Prison without the Possibility of Parole", Journal of Civil Rights and Economic Development 2012 (26(2)), $387-413$.

Lappi-Seppälä, T., "Juvenile justice without a juvenile court: A note on Scandinavian exceptionalism", in Zimring, F.E., Langer, M. and Tanenhaus, D.S. (eds.), Juvenile Justice in Global Perspective (New York: NYU Press), 63-118.

Liefaard, T., (2015). "Juvenile justice from an international children's rights perspective", in Vandenhole, W., Desmet, E., Reynaert, D. and Lembrechts, S., Routledge International Handbook of Children's Rights Studies (Routledge, 2015), 250-272.

Liefaard, T., Deprivation of liberty of children in light of international human rights law and standards. Antwerp: Intersentia, 2008).

Linde, R., "From rapists to superpredators: What the practice of capital punishment says about race, rights and the American child", The International Journal of Children's Rights 2011 (19(1)), 127-150.

Lynch N. (2019), Protective measures for children accused or convicted of serious crimes in O'Brien, W. and Foussard, C. (eds.), Violence Against Children in the Criminal Justice System: Global Perspectives on Prevention (Routledge, 2019).

Lynch, N. (2018a), "Towards a principled legal response to children who kill. Youth Justice" 2018 (18(3)), 211-229.

Lynch, N. (2018b), “Human rights for 'Hard Cases': Alternatives to imprisonment for serious offending by children and youth", in Human Rights and Incarceration (Palgrave Macmillan, Cham), 153-179.

Lynch, N. (2018c), "Manifest injustice? The judiciary as moderator of penal excess in the sentencing of youth for murder", The Howard Journal of Crime and Justice 2018 (57(1)), 57-76.

Lynch, N. and Liefaard, T., (2020) "What is Left in the 'Too Hard Basket'? Developments and Challenges for the Rights of Children in Conflict with the Law", The International Journal of Children's Rights 2020 (28), 1-23

Matthews, S., Schiraldi, V. and Chester, L., (2018). "Youth Justice in Europe: Experience of Germany, the Netherlands, and Croatia in Providing Developmentally Appropriate Responses to Emerging Adults in the Criminal Justice System", Justice Evaluation Journal 2018 (1(1)), 59-81.

Miller, S. L. and Miller, S.L., After the crime: The power of restorative justice dialogues between victims and violent offenders (NYU Press, 2011).

Muncie, J., "Policy transfers and 'what works': Some reflections on comparative youth justice”, Youth Justice, 2001 (1(3)), 27-35.

Musila, G. M., "Challenges in establishing the accountability of child soldiers for human rights violations: Restorative justice as an option", African Human Rights Law Journal 2005 (5), 321. 
Namuo, C., "Victim Offender Mediation: When Divergent Paths and Destroyed Lives Come Together for Healing", Georgia State University Law Review 2015 (32), 577 .

Nelken, D., Comparative criminal justice. Making sense of difference (London: SAGE, 2010).

Nowak M., The United Nations Global Study on Children Deprived of Liberty (Geneva: United Nations, 2019).

O'Brien, W. and Fitz-Gibbon, K., “'Cemented in their cells': a human rights analysis of Blessington, Elliott and the life imprisonment of children in New South Wales", Australian Journal of Human Rights 2016 (22(1)), 111-133.

O'Brien, W. and Fitz-Gibbon, K., "Can human rights standards counter Australia's punitive youth justice practices?", The International Journal of Children's Rights 2018 (26(2)), 197-227.

Packer, H.L., The Limits of the Criminal Sanction (Stanford University Press, 1968).

Persson, M., Caught in the Middle? Young offenders in the Swedish and German criminal justice systems (Lund: Lund University, 2017) (Media-Tryck).

Press Association, "Varadkar: Ireland gripped by 'epidemic of gender-based violence", Irish Examiner, 6 November 2019.

Pruin, I. and Dünkel, F., "Better in Europe? European responses to young adult offending", London, England: Transition to Adulthood (2015).

Rap, S.E., The participation of juvenile defendants in the youth court. A comparative study of juvenile justice procedures in Europe (Doctoral dissertation, 2013, Utrecht University) (Amsterdam: Pallas Publications).

Reef, J., Jeltes, M. and van den Brink, Y.N., De PIJ-maatregel doorgelicht. Juridische grondslagen, populatiekenmerken, gedragsverandering en recidive (Nijmegen: Wolf Legal Publishers, 2020).

Ryan, J.P., Abrams, L.S. and Huang, H., "First-time violent juvenile offenders: Probation, placement, and recidivism”, Social Research (2014). DoI: 10.1093/swr/svuoo4.

Schmidt, E.P., Rap, S.E. and Liefaard, T., "Young Adults in the Justice System: The Interplay between Scientific Insights, Legal Reform and Implementation in Practice in The Netherlands", Youth Justice 2020, 1-20.

Scott, E. S. and Steinberg, L., Rethinking juvenile justice (Harvard University Press, 2009). Steinberg, L. and Scott, E.S., "Less Guilty by Reason of Adolescence. Developmental Immaturity, Diminished Responsibility, and the Juvenile Death Penalty", American Psychologist 2003 (58(12)), 1009-1018.

Steinberg, L., "Adolescent brain science and juvenile justice policymaking", Psychology, Public Policy, and Law 2017 (23(4)), 410-420.

Stone, N., "Children Who Murder: Indeterminate Sentencing in Law and Practice", Youth Justice 2018 (18(1)), 82-95. 
Trulson, C. and Caudill, J., "Juvenile homicide offender recidivism”, Journal of Criminal Psychology 2017 (7(2)), 93-104.

Tulkens, F., "The paradoxical relationship between criminal law and human rights", Journal of International Criminal Justice (9(3)), 577-595.

Uit Beijerse, J. and van Swaaningen, R., "The Netherlands: Penal welfarism and risk management", in Muncie, J. and Goldson, B. (eds.), Comparative youth justice: Critical issues, $65^{-78}$.

Umbreit, M.S., Vos, B., Coates, R.B. and Brown, K.A., Facing violence: The path of restorative justice and dialogue. (Monsey (NY): Criminal Justice Press, 2003).

UN Committee on the Rights of the Child (2007), General Comment No. 10, Children's rights in juvenile justice (CRC/C/GC/10), 25 April 2007.

UN Committee on the Rights of the Child (2009), Concluding Observations of the Committee on the Rights of the Child: The Kingdom of the Netherlands (CRC/C/ $\mathrm{NLD} / \mathrm{CO} / 3)$.

UN Committee on the Rights of the Child (2013), General Comment No. 14, The right of the child to have his or her best interests taken as a primary consideration (art. 3, para. 1) (CRC/C/GC/14), 29 May 2013.

UN Committee on the Rights of the Child (2014), Concluding observations on the combined third and fourth periodic reports of Germany (CRC/C/DEU/CO/3-4), 25 February 2014.

UN Committee on the Rights of the Child (2015a), Concluding observations on the fourth periodic report of the Netherlands (CRC/C/NLD/CO/4), 16 July 2015.

UN Committee on the Rights of the Child (2015b), Concluding observations on the fifth periodic report of Sweden (CRC/C/swE/CO/5), 6 March 2015.

UN Committee on the Rights of the Child (2017), Concluding observations on the fifth periodic report of Denmark (CRC/C/DNK/CO/5), 26 October 2017.

UN Committee on the Rights of the Child (2018), Concluding observations on the combined fifth and sixth periodic reports of Norway (CRC/C/NOR/CO/5-6), 4July 2018. UN Committee on the Rights of the Child (2019a), General Comment No. 24, Children's rights in the child justice system (CRC/C/GC/24), 18 September 2019.

UN Committee on the Rights of the Child (2019b), Concluding observations on the combined fifth and sixth periodic reports of Belgium (CRC/C/BEL/CO/5-6), 28 February 2019.

UN Human Rights Committee, General Comment No. 35, Article 9 (Liberty and security of person) (CCPR/C/GC/35), 16 December 2014.

UNODC (2019), Global Study on Homicide. Homicide: extent, patterns, trends and criminal justice response, UnODC, Vienna.

van den Brink, Y.N., "Pre-trial detention in the Dutch juvenile justice system: Bridging welfare and justice", in Christiaens, J. (ed.), It's for Your Own Good: Researching Youth Justice Practices (Brussels: vUB PRESS, 2015), 195-210. 
van den Brink, Y.N. (2019a), "Tussen strafrecht en hulpverlening. Grondslagen, praktijk en schurende paradigma's in het Nederlandse jeugdstrafrecht”, Tijdschrift voor Jeugd en Kinderrechten (2): 144-162.

van den Brink, Y.N. (2019b)., "Young, Accused and Detained; Awful, But Lawful?

Pre-Trial Detention and Children's Rights Protection in Contemporary Western

Societies", Youth Justice 2019 (19(3)), 238-261.

van der Laan, A.M. et al., Adolescentenstrafrecht. Beleidstheorie en eerste empirische bevindingen (The Hague: WODC, 2016).

van der Merwe, A. and Skelton, A., “Victims' Mitigating Views in Sentencing Decisions:

A Comparative Analysis", Oxford Journal of Legal Studies 2014 (35(2)), 355-372.

van Ham, T. and Ferwerda, H., Het nut van vasthouden. Literatuuronderzoek naar de effecten van detentie op jongeren en adolescenten (Arnhem: Bureau Beke, 2019).

van Zyl Smit, D., Life imprisonment: A global human rights analysis (Harvard University Press, 2019).

Von Hirsch, A., "Proportionate sentences for juveniles: How different than for adults?", Punishment \& Society 2001 (3(2)), 221-236.

Wartna, B.S.J., Alberda, D.L. and Verweij, S., Wat werkt in Nederland en wat niet? Een meta-analyse van Nederlands recidiveonderzoek naar de effecten van strafrechtelijke interventies (The Hague: wodC, 2013).

Weijers, I., "Grondslagen van jeugdstrafrecht", in Weijers, I. and Imkamp, F. (eds.), Jeugdstrafrecht. In internationaal perspectief(The Hague: Boom Juridische uitgevers, 2014), 31-52.

Yun, L.S., "The United States stands alone: An international consensus against juvenile life without parole sentences", Southern California Interdisciplinary Law Journal $2010(20), 727$.

\section{Table of Cases}

Aleksandr Aleksandrovv Russia, ECtHR 27 March 2018, Appl. No. 14431/o6.

District Court Midden-Nederland 13 July 2018, ECLI:NL:RBMNE:2018:3274.

District Court Midden-Nederland 30 July 2021, ECLI:NL:RBMNE:2O21:4111.

Ilnseher v Germany, ECtHR 2 February 2017, Appl. nos. 10211/12 and 27505/14.

J.M. v Denmark, ECtHR 13 November 2012, Appl. No. 34421/o9.

L.C.B. $v$ the United Kingdom ECtHR 9 June 1998, Appl. No. 14/1997/798/10o.

Markham and Edwards $v R$ [2017] EwCA Crim 739.

Osman $v$ the United Kingdom ECtHR 28 October 1998, Appl. No. 87/1997/871/1083. $R v$ McGill, Hewitt and Hewitt [2017] EWCA 1228. 